Dr MIOMIR GATALOVIĆ, naučni saradnik

Institut za savremenu istoriju

Beograd, Trg Nikole Pašića 11

gatalovic@gmail.com

UDK 94(497.115)"1964/1965"

323.1(497.115)"1964/1965"

originalan naučni rad

primljeno: 6. april 2016.

prihvaćeno: 18. maj 2016.

\title{
UTICAJ OTVARANJA NACIONALNOG PITANJA U JUGOSLAVIJI NA KREIRANJE DRŽAVNE POLITIKE PREMA KOSOVU I METOHIJI 1964-1965.
}

APSTRAKT: $U$ radu se na osnovu građe Arhiva Jugoslavije i Arhiva Srbije, objavljenih izvora i literature analizira u kojoj meri je otvaranje nacionalnog pitanja u Jugoslaviji tokom 1964. i 1965. godine, podstaknuto narastajućom ekonomskom krizom, uticalo na kreiranje državne politike prema Kosovu i Metohiji. Istraženi su razlozi koji su doveli do veće kadrovske zastupljenosti funkcionera sa Kosova i Metohije u saveznim organima i opisane okolnosti formiranja Fonda federacije za kreditiranje privredno nedovoljno razvijenih republika i krajeva, kojim je Autonomna pokrajina Kosovo i Metohija u investicionim potraživanjima izjednačena sa nerazvijenim republikama Jugoslavije.

KLJUČNE REČI: Kosovo i Metohija, nacionalno pitanje, Jugoslavija, ekonomska kriza, Josip Broz Tito, državna politika, Savez komunista Jugoslavije, nacionalna manjina

Jugoslavija je od 1958. godine intenzivirala ulaganja u brži razvoj Kosova i Metohije kako bi ono, kao najnerazvijenije područje, uhvatilo korak sa ostatkom države. U pitanju je bila državna politika zasnovana na uverenju da će društvena, privredna, prosvetna, kulturna i zdravstvena investiranja u Kosovo i Metohiju podstaći bržu integraciju Albanaca, koji su činili dve trećine stanovništva ove teritorije, u jugoslovensku zajednicu, suzbiti iredentizam i opovrgnuti antijugoslovensku propagandu koju je širilo najviše rukovodstvo susedne Albanije. Budući da je jugoslovenska državna politika $\mathrm{u}$ ovo vreme kreirana $\mathrm{u}$ vrhu Saveza komunista Jugoslavije

* Rad je deo projekta Konflikti i krize: saradnja i razvoj u Srbiji i regionu u 19. i 20. veku (47030) koji finansira Ministarstvo prosvete, nauke i tehnološkog razvoja Republike Srbije. 
(SKJ), takva opredeljenja su bila potvrđena na Sedmom kongresu SKJ, održanom od 22. do 26. aprila 1958, kao i na proširenoj sednici Izvršnog komiteta CK SKJ od 2. marta 1959. Teritorijalno zaokruživanje Autonomne Kosovsko-metohijske oblasti (AKMO) izvršeno je krajem 1959. godine, kada je ona proširena dodavanjem katastarskih opština centralne Srbije od kojih je formirana nova opština Leposavić na severu Kosova i Metohije. Korak dalje predstavljalo je prerastanje AKMO u Autonomnu pokrajinu Kosovo i Metohiju (APKM), što je potvrđeno Ustavom Socijalističke Federativne Republike Jugoslavije (SFRJ) od 7. aprila, Ustavom Socijalističke Republike Srbije (SRS) od 9. aprila i Statutom APKM od 10. aprila 1963. $\mathrm{Na}$ taj način jedino je SR Srbija u okviru SFRJ imala u svom sastavu pokrajine, i to čak dve: AP Vojvodinu i AP Kosovo i Metohiju. U takvim okolnostima početni impulsi otvaranja nacionalnog pitanja u Jugoslaviji, koje je od kraja Drugog svetskog rata planski bilo marginalizovano, mogu se zapaziti još na proširenoj sednici Izvršnog komiteta CK SKJ, održanoj od 14. do 16. marta 1962, kada je Edvard Kardelj potencirao samostalnost i pravo na samoopredeljenje jugoslovenskih republika kao put ka konfederalnom državnom uređenju, dok su uglavnom srpski kadrovi nastojali da očuvaju Jugoslaviju kao centralističku federaciju sa dominantnom ulogom SKJ. U pitanju su bile prve ozbiljne pukotine $u$ jedinstvu najvišeg rukovodstva Jugoslavije, koja je bila višenacionalna država sa brojnim nacionalnim manjinama - tzv. narodnostima, a posle ove sednice u prvi plan je istaknut Aleksandar Ranković kao najbliži saradnik i potencijalni naslednik Josipa Broza Tita. ${ }^{1}$

Na sednici Izvršnog komiteta CK SKJ, održanoj 18. i 19. februara 1963, E. Kardelj je kritikovao tendencije predratnog „unitarističkog jugoslovenstva“, istakavši da „svako može da kaže da je Jugosloven ako neće da

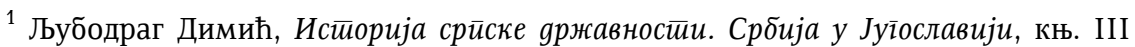
(Нови Сад: Будућност, 2001), 368; Branko Petranović, Istorija Jugoslavije 1918-1988. Socijalistička Jugoslavija, knj. III (Beograd: Nolit, 1988), 349; Коста Николић, Србија у Тийовој Јуі̄ославији (1945-1980) (Београд: Завод за уџбенике, 2011), 237; Dušan Bilandžić, Historija Socijalističke Federativne Republike Jugoslavije: glavni procesi 1918-1985 (Zagreb: Školska knjiga, 1985), 264; Miomir Gatalović, „Prerastanje Autonomne Kosovsko-metohijske oblasti u Autonomnu pokrajinu Kosovo i Metohiju 1959-1963.", Istorija 20. veka XXXIII, br. 1 (2015), 77-94; Mile Bjelajac, „Karakter jugoslovenskog centralizma u svetlu analize tajne sednice Izvršnog komiteta Centralnog komiteta Saveza komunista Jugoslavije marta 1962. godine“, u: Dijalog povjesničara-istoričara 7, Zbornik radova, urednici Hans-Georg Fleck i Igor Graovac (Zagreb: Friedrich Naumann Stiftung, 2003) 373-390; Početak kraja SFRJ. Stenogram i drugi prateći dokumenti proširene sednice Izvršnog komiteta CK SKJ održane 14-16. marta 1962. godine, priredio Miodrag Zečević (Beograd: Printer Komerc, 1998), 7; Arhiv Jugoslavije (AJ), fond 507, Savez komunista Jugoslavije (SKJ), III/88, Stenografske beleške sa proširene sednice Izvršnog komiteta Centralnog komiteta SKJ (IK CK SKJ), 14-16. mart 1962. 
se opredeli ni za jednu postojeću nacionalnost, s tim da „Jugosloven“ ne treba shvatiti nacionalistički već kao pripadnost jugoslovenskoj socijalističkoj zajednici“. Tokom diskusije su kritikovane pojave „nacionalizma i republičke uskogrudosti“, zatraženo podsticanje zbližavanja nacionalnih kultura jugoslovenskih republika i dati predlozi za penzionisanje poslanika Skupštine Narodne republike Srbije (NRS) Mehmeta Hodže, upućivanje u savezne organe Fadilja Hodže i imenovanja u kosmetske organe: Dušana Mugoše za sekretara Pokrajinskog komiteta Saveza komunista Srbije (PK SKS), Ilijaza Kurtešija za organizacionog sekretara PK SKS, Stanoja Aksića za predsednika Pokrajinske skupštine, Ali Šukrije za predsednika Pokrajinskog izvršnog veća, Džavida Nimanija za predsednika Pokrajinskog Socijalističkog saveza radnog naroda (SSRN), Veli Deve za predsednika Pokrajinskog Saveza sindikata i Branislava Škembarevića za predsednika Komisije za ideološki rad. Na sastanku Grupe za proradu teza za pretkongresnu aktivnost u vezi sa sazivanjem Osmog kongresa SKJ, održanom 27. i 28. februara 1963, istaknuto je da bi bilo opasno da se „ide ka jugoslovenstvu u bilo kojoj nacionalnoj kategoriji“, već da se ono gradi kao „zajednica radnih ljudi koja počiva na samoupravljanju i socijalizmu“, odnosno da se partijskom članstvu objasni da se „ne ide na prevazilaženje nacije da bi se stvorila jugoslovenska nacija". ${ }^{2}$

Na savetovanju o međunacionalnim odnosima u Jugoslaviji, održanom 11. i 12. februara 1964. u CK SKJ, predsednik Komisije za ideološki rad Centralnog komiteta Saveza komunista Srbije (CK SKS) Milojko Drulović je izjavio da u Srbiji postoje velike razlike u ekonomskoj razvijenosti, što je potkrepio mišlju: „Na nekim područjima imamo uslove za moderno privređivanje i život na nivou evropskom, u drugom se takoreći tek izvlačimo iz srednjeg veka“. Shodno tome, zatraženo je da se razlike prevaziđu produbljivanjem socijalističke svesti o zajedničkim interesima svih naroda Jugoslavije, razvijanjem opštejugoslovenskog socijalističkog patriotizma i internacionalizma, kao i doslednom borbom protiv svih nacionalističkih ili hegemonističkih shvatanja. Apelovano je da se suzbija prisustvo „nacionalnih mitova i romantike u sadržajima savremenog stvaranja" i svako predimenzioniranje događaja i ličnosti iz nacionalne istorije. Povodom priprema za Osmi kongres SKJ, na sednici Izvršnog komiteta SKJ održanoj 21. februara 1964. Josip Broz Tito je ukazao da je „važno da se na Kongres izađe sa izvesnim zaključcima u kojima bi se još jednom naglasila politika Partije $u$

${ }^{2}$ AJ, 507, SKJ, III/96, Stenografske beleške sa sednice IK CK SKJ, 18-19. februar 1963; AJ, 507, SKJ, III/96, Predlog za penzionisanje političkih i državnih funkcionera, 1963; AJ, 507, SKJ, III/96, Posebni predlozi. Drugu Veljku Vlahoviću šalje A. Ranković, 1963; AJ, 507, SKJ, II/23, Stenografske beleške sa sastanka Grupe u vezi materijala za teze za pretkongresnu aktivnost, 27-28. februar 1963. 
nacionalnom pitanju“, iza čega se krio pritisak narastajuće ekonomske krize u državi. Naime, na prehrambene proizvode i stanovanje se trošilo oko 3/4 budžeta porodice, dok su one slabije plaćenih radnika trošile $85-90 \%$ dohotka. Pojedine porodice su jele meso samo jedanput mesečno kada prime platu i bile veoma zadužene, što je dovodilo do komentara da se „mnogo gradi, da je naš položaj u preduzeću bolji nego pre rata, iako nema onih prava i pravde o kojima se priča, bolje je u slučaju bolesti i nezaposlenosti, ali se teško živi“. Shodno tome, Izvršni komitet CK SKS je 6. marta sačinio analizu o važnijim privrednim objektima na području SR Srbije o čijoj izgradnji je Savezno izvršno veće (SIV) donelo odluke, pa je na teritoriji AP Kosovo i Metohija istaknuta neophodnost izgradnje termoelektrane Kosovo III, koju je finansirala Jugoslovenska investiciona banka, i zatražena izrada planova za podizanje termoelektrane Kosovo IV i razvoj rudnika i topionice "Trepča" u Zvečanu. ${ }^{3}$

Šesti plenum CK SKJ, održan 16. marta 1964, bio je posvećen pripremama za sazivanje Osmog kongresa SKJ. U uvodnom referatu Veljko Vlahović se založio za razvijanje demokratskog centralizma koji bi bio „na kursu postepenog ali bržeg porasta životnog standarda radnih ljudi“. Naglašeno je da „društvena zajednica posvećuje posebnu pažnju bržem razvitku proizvodnih snaga u privredno nedovoljno razvijenim republikama i krajevima, odnosno da obezbeđuje sredstva i preduzima druge mere da bi se postepeno smanjivale razlike u materijalnim uslovima društvenog života i rada radnih ljudi i da bi se što skladnije razvijala naša privreda kao celina, u interesu kako nerazvijenih tako i razvijenih područja“. Pri tome, sredstva koja jugoslovenska zajednica odvaja u tu svrhu označena su kao „stalna proporcija u raspodeli nacionalnog dohotka, usklađena sa mogućnostima i zadacima naše privrede i sa potrebama daljeg ubrzanog privrednog razvoja tih područja“, dok bi donošenjem Sedmogodišnjeg perspektivnog društvenog plana bio obezbeđen „brz razvoj proizvodnje, produktivnosti rada i nacionalnog dohotka“. Koliko je situacija bila ozbiljna svedoči činjenica da po otvaranju diskusije niko od funkcionera nije želeo da se prvi javi za reč, pa je J. B. Tito bio prinuđen da uputi opomenu: „Ako budete ovdje šutili ko će onda znati šta mislite o tome šta smo mi ovde napisali... Nije dosta kazati samo, „slažem se“, nego treba izneti ono sa čime se ne slažete, jer ima stvari na koje se različito gleda". ${ }^{4}$

${ }^{3}$ AJ, 507, SKJ, VIII, II/4-d-(28-33), K-25, Savetovanje o aktuelnim ideološkim pitanjima održano u CK SKJ, 11-12. februar 1964; AJ, 507, SKJ, III/100, Zapisnik sa sednice IK CK SKJ, 21. februar 1964; AJ, 507, SKJ, III/100, O nekim problemima naše radničke klase, 19. februar 1964; Arhiv Srbije (AS), fond Đ-2, Savez komunista Srbije (SKS), kutija (k.) 6, Važniji privredni objekti na području SRS, 6. mart 1964.

${ }^{4}$ AJ, 507, SKJ, II/24, Stenografske beleške sa Šestog plenuma CK SKJ, 16. mart 1964. 
U nastavku plenuma Mika Špiljak je ocenio da se $u$,jugoslovenskim fabrikama gomila suvišna radna snaga“, koja uzrokuje nisku produktivnost i lične dohotke, a da radnici „nemaju interesa da podižu norme s obzirom da za to nisu ničim podsticani“. Kako je istakao: „S jedne strane osećamo da treba povećati lične dohotke i standard, a na drugoj strani nemamo dohotka, nemamo odakle da povećavamo standard“. U oblasti investiranja Špiljak je primetio da „najveći deo svih objekata košta više nego što smo planirali“ i da se rentabilnost svuda pokazuje „nižom nego što je u elaboratima pokazana“. Milojko Drulović je rekao da veliki problem na području Srbije predstavljaju niski lični dohoci, ukazavši da na području SR Srbije živi 55\% seoskog stanovništva, u AP Kosovo i Metohija čak 85\%, a u SR Sloveniji svega 27\%. Na kraju plenuma, J. Broz Tito je zaključio da su u jugoslovenskoj privredi godinama postojali prenapregnuti planovi i da su se „plafoni uvek takoreći probijali u investicijama, i u saveznim, i u republičkim i komunalnim". Pri tome je ukazao na velike privredne disproporcije među različitim delovima Jugoslavije: „Mi imamo krajeva gde je visoka produktivnost rada koja je dostigla evropski nivo, ali imamo i takvih gde je vrlo niska produktivnost rada i koja nije ni $50 \%$ od produktivnosti u drugom mestu“. S druge strane, u Komisiji za ideološki rad CK SKJ održan je 28. marta 1964. sastanak Grupe za međunacionalne odnose na kojem je saopšteno da je u administrativnoj fazi razvoja socijalizma postojala „iluzija o potpunom i definitivnom rešenju nacionalnog pitanja“, ali da je razvitak društvenog samoupravljanja „postepeno počeo da ponovo pokreće pitanje nacionalnog odnosa“. Veljko Vlahović je zamerio što se zbog „rešavanja nacionalnog pitanja“ problemi privrede „tovare na čitavu zajednicu“, umesto da se ide putem pronalaženja najboljeg ekonomskog modela njihovog rešavanja, primetivši da je dalji razvoj nerazvijenih oblasti „,jedan od krupnijih problema“. ${ }^{5}$

U takvim okolnosti, Sekretarijat PK SKS za Kosovo i Metohiju je 7. aprila 1964. uputio „Pismo“ Izvršnom komitetu CK SKS u kojem se navodi da je neophodno da se ovo partijsko telo „upozna sa oštrinom problema“ koji proističu iz ekonomsko-političke situacije „radi zajedničkog sagledavanja mogućih rešenja i obezbeđivanja potrebne pomoći“. U „Pismu“ je naglašeno da je AP Kosovo i Metohija najnerazvijeniji deo SR Srbije i SFRJ, da je privredni razvoj Pokrajine u periodu od 1945. do 1957. bio „spor i neznatan“, da se Jugoslavija tada nalazila u teškoj situaciji zbog čega nisu pokretana pitanja većih ulaganja i da je od 1957. do 1963. APKM počela brže da se razvija zahvaljujući investicijama koje su dovele do zapošljavanja 38.400 novih radnika i povećanja nacionalnog dohotka za 9.440 dinara po stanov-

${ }^{5}$ AJ, 507, SKJ, II/24, Stenografske beleške sa Šestog plenuma CK SKJ, 16. mart 1964; AJ, 507, SKJ, VIII, II/4-a-(1-48), k. 21, Stenografske beleške sa sastanka Grupe u Komisiji za ideološki rad CK SKJ o međunacionalnim pitanjima, 28. mart 1964. 
niku. Stopa rasta, međutim, u periodu 1957-1963. ostvarena je samo 54\%, od predviđenih 305 milijardi dinara obezbeđeno je 194 milijardi ili $64 \%$ i od 71.655 planiranih novih radnih mesta omogućeno je 55\%. Time je državna politika prema Kosovu i Metohiji nepotpuno ostvarena, što nije bilo u skladu sa Programom SKJ, Ustavom SFRJ, Ustavom SR Srbije, društvenim planovima i drugim državnim aktima. Direktne posledice bile su zaostajanje i produbljivanje razlika u razvijenosti ovog područja u odnosu na druge jugoslovenske krajeve, zaoštravanje ekonomskog neraspoloženja masa i pogoršanje međunacionalnih odnosa. Rukovodstvo Kosova i Metohije je često bilo $\mathrm{u}$ „neugodnom položaju da samostalno ističe probleme svog područja ne nailazeći na razumevanje i podršku drugih", pre svega republičkih kadrova i političkih tela. ${ }^{6}$

U „Pismu“ Sekretarijata PK SKS za KM priloženi su statistički podaci prema kojima je od 1945. do 1964. na jednog stanovnika u Jugoslaviji prosečno investirano 604.320 dinara i na Kosovu i Metohiji 50\% od toga, pri čemu je vrednost osnovnih sredstava po jednom stanovniku u APKM iznosila svega 34,7\% od proseka u SFRJ. U AP Kosovo i Metohija godišnji priraštaj stanovništva iznosio je 24.000 lica, a prosečna godišnja zaposlenost 3.750 lica. Na zapošljavanje je zvanično čekalo 15.000-20.000 lica, a nezvanično se pretpostavljalo da ih ima tri do četiri puta više. Pored najvećeg prirodnog priraštaja u Jugoslaviji, na Kosovu i Metohiji je bilo najviše poljoprivrednog stanovništva $64 \%$ (u SFRJ 50\%), najveća gustina naseljenosti 88,9 stanovnika na $1 \mathrm{~km}^{2}$ (SFRJ 72,4), najmanje učešće aktivnog stanovništva 35\% (SFRJ 55\%), najmanje učešće zaposlenih u ukupnom broju stanovnika $8,4 \%$ (SFRJ 16,8\%), najveći broj članova domaćinstva 6,29 (SFRJ 3,98), najveće učešće mladog stanovništva do 14 godina 42,3\% (SFRJ 31,5\%), najveći broj nepismenih 43,3\% (SFRJ 21,1\%), najveća smrtnost stanovništva od 14,8 na 1.000 stanovnika (SFRJ 9,9) i najveća smrtnost odojčadi - 147 na 1.000 živorođene dece (SFRJ 83,9). Česti su bili prekidi u napajanju električnom energijom, dotrajao je bio stambeni fond, propusna moć železničke pruge Kraljevo - Kosovo Polje - Skoplje i Niš Kosovo Polje - Peć veoma ograničena, modernizacija puta Peć-Prizren i pruge Metohija-Prizren vršena je 14 godina, a modernizacija puta Kosovska Mitrovica - Uroševac 10 godina. Obuhvat dece od 7 do 12 godina osnovnim školom bio je $89,3 \%$, a od 13 do 15 godina $47,4 \%$. Većina škola radila je u dve do tri smene zbog nedovoljnog prostora, pri čemu je školski prostor po jednom učeniku u osnovnim školama 1958/59. godine iznosio $1,54 \mathrm{~m}^{2} \mathrm{i}$ $1962 / 63$. godine $1,42 \mathrm{~m}^{2}$, a u srednjim školama $3,72 \mathrm{~m}^{2}$ naprema $3,28 \mathrm{~m}^{2}$. Broj bolesničkih postelja na 1.000 stanovnika bio je 1,4 (SR Srbija 4,1 i

\footnotetext{
${ }^{6}$ AS, Đ-2, SKS, K-7, Pismo Izvršnom komitetu (IK) CK SKS, 7. april 1964.
} 
SFRJ 4,4), na jednu ambulantu je dolazilo 12.507 pacijenata (SR Srbija 7.030 i SFRJ 6.136) i na jedan dispanzer za decu 137.537 pacijenata (SR Srbija 59.328 i SFRJ 33.409). Jedino su zabeleženi rast privredne produktivnosti od prosečno $7 \%$ godišnje i ličnih dohodaka za $6,5 \%$, ali je lična potrošnja i dalje bila ispod proseka za Jugoslaviju. ${ }^{7}$

„Pismo“ PK SKS za KM otkriva da je do kraja 1965. planirano zapošljavanje 10.500 lica godišnje, a da je do kraja 1963. realizovano zapošljavanje oko 4.000 lica ili 38\%. Od planiranih 33,3 milijardi dinara iz Fonda za razvoj nerazvijenih područja odobreno je do kraja 1963. godine svega 12 milijardi. Na kraju „Pisma“ izložene su mogućnosti i mere za brži razvoj Kosova i Metohije od 1964. do 1970. godine, koje nisu predviđale „političke investicije" nego efikasnije iskorišćavanje postojećih sirovina u pravcu njihove prerade i finalizacije. Na Kosovu i Metohiji se nalazilo 64\% jugoslovenskih rezervi olova i cinka, 50\% rezervi lignita, trećina rezervi hroma i magnezita, kao i velike količine nikla, gvožđa, mangana, kaolina, leucita, mermera i azbesta. Kako je Jugoslaviji bilo potrebno 2,4 puta više električne energije predloženo je da se ona proizvodi na Kosovu i Metohiji, ali i da se razvija hemijska, metalna, prehrambena, drvna, tekstilna, građevinska, duvanska industrija i industrija kože i obuće, unapredi poljoprivreda, izgrade akumulacije na Ibru i Lepencu, proširi saobraćajna mreža. Istaknuto je da bi AP Kosovo i Metohija, ukoliko bi tempo porasta proizvodnje godišnje bio $23 \%$, do 1970 . godine ostvarila dohodak po stanovniku od $71 \%$ jugoslovenskog nivoa. Shodno tome, zatraženo je da Kosovo i Metohija zadrži poseban tretman u saveznim i republičkim planovima, zakonima i programima razvoja nerazvijenih područja, da se sredstva Fonda za nerazvijena područja raspodeljuju prema stepenu nerazvijenosti područja i da uslovi dodeljivanja sredstava budu mnogo povoljniji od opštih uslova $u$ državi, da krupna preduzeća grade svoje pogone na nerazvijenim područjima, da se podstakne izvoz sa Kosova i Metohije, povećaju geološka ispitivanja i prošire kapaciteti školstva, zdravstva, socijalnog staranja, kulture i komunalne izgradnje. ${ }^{8}$

Na sednici Izvršnog komiteta CK SK Srbije, 22. maja 1964, u okviru razmatranja „Pisma“ PK SKS za KM, konstatovano je da je u razdoblju do 1957. godine: investirano u brži razvoj AP Kosovo i Metohija 32 milijarde dinara; prosečna stopa rasta proizvodnje od 1947. do 1956. iznosila 3,5\%, od 1957. do 1963. godine 7,9\%; povećano učešće industrije u ukupnoj privredi sa $24 \%$ u 1948. na $38 \%$ u 1963. i učešće društvenog sektora sa $43 \%$ na $65 \%$; broj zaposlenih lica povećan sa 25.000 na 85.000 i nacionalni dohodak sa 39.000 na 64.000 dinara. Usporeniji tempo razvoja AP Kosovo i Metohija

\footnotetext{
${ }^{7}$ Isto.

${ }^{8}$ Isto.
} 
ocenjen je kao posledica nasleđene zaostalosti, visokog prirodnog priraštaja, nedovoljnog i sporog investiranja, teškoća u realizaciji garantovanih sredstava, otkazivanja kredita Jugoslaviji od strane Sovjetskog Saveza u periodu od 1957. do 1961. godine, kašnjenja u razradi i donošenju propisa za sprovođenje mera i planiranih proporcija razvoja. No, tempo razvoja Kosova i Metohije bio je usporen ne samo u odnosu prema postignutom nivou u Jugoslaviji, već i prema nedovoljno razvijenim jugoslovenskim republikama. Stoga su kritikovane pojave neskromnosti u zahtevima investitora, neopravdanih prekoračenja odobrenih investicija, slabe organizacije proizvodnje, nedovoljnog korišćenja kapaciteta, javašluka, nediscipline i primitivizma, nebrige i nepravilnog odnosa prema stručnom kadru, lokalističkih i partikularističkih tendencija. Deo odgovornosti, kako je naznačeno, snosi rukovodstvo Kosova i Metohije „usled nesnalaženja i lutanja, subjektivnih slabosti i grešaka što je znatno uticalo na usporavanje razvoja i slabije opšte efekte uloženih sredstava“. Posle konstatacije da je razvoj APKM uvek bio primarni cilj politike rukovodstva SR Srbije, zatraženo je da se više iskoriste prirodni potencijali Kosova i Metohije, isprave slabosti i greške u radu pokrajinskih, republičkih i saveznih organa, povećaju obim i dinamika investicija i u narednom periodu obave razgovori sa pokrajinskim funkcionerima. ${ }^{9}$

U diskusionom delu sednice Izvršnog komiteta CK SKS, Jovan Veselinov je ukazao da „drugovi sa Kosmeta u „Pismu“ nisu bili dovoljno kritični sami prema sebi“, dok je S. Penezić Krcun ocenio da politika daljeg razvoja nerazvijenih područja nije do kraja definisana i da je jugoslovenska federacija deo pomoći upućivala samostalno, a drugi deo preko SR Srbije koji je u poslednje tri godine iznosio 10 milijardi dinara. Dušan Petrović Šane je pozvao pokrajinske rukovodioce D. Mugošu i Dž. Nimanija da pojasne „pojave otpora raznih institucija i organa, Federacije i Republike u sprovođenju naše politike na Kosmetu, odnosno žalbe da se Kosovo i Metohija ne tretira kao jedinstven deo Srbije u smislu dobijanja dovoljno pomoći“. Mugoša je odgovorio da su pokrajinski funkcioneri dugo razmišljali da li da napišu „Pismo“, ali da su se na taj korak odlučili zbog "cele situacije, raspoloženja masa i kadrova i nagomilanih protivrečnosti“. Njihov cilj je bio da se Izvršni komitet CK SKS založi da se položaj AP Kosovo i Metohija bolje tretira u izradi Sedmogodišnjeg plana razvoja i da se političko rukovodstvo SR Srbije detaljno upozna sa svim teškoćama sa terena gde vladaju "nacionalne protivrečnosti i propaganda iz Albanije“. Požalivši se da su kod njega dolazili „drugovi iz Pokrajine" sa različitih državnih nivoa da kritikuju stanje u AP Kosovo i Metohija, ukažu kako

\footnotetext{
${ }^{9}$ AS, Đ-2, SKS, K-7, Stenografske beleške sa sednice IK CK SKS, 22. maj 1964.
} 
nemaju dovoljno sredstava i da se odugovlači sa rešavanjem osnovnih pitanja, on je naglasio da je bilo slučajeva da su „republički organi i ustanove ponekad gledali na sva pitanja koja smo mi pokretali sa Kosova i Metohije kao da zadiremo u neka prava koja nisu naša ili da smo dosadili sa pokretanjem tih pitanja“. Zatim je Mugoša pozvao „drugove iz Republike“ da pošalju stručnjake na Kosovo i Metohiju, da se olakša i podstakne sprovođenje planova umesto da se nailazi na „otežavanje od strane pojedinih saveznih i republičkih organa" i da se ojačaju organi društvenog upravljanja i pojača tehnička pomoć od strane razvijenih preduzeća, što je, pak, dovelo do opšteg međusobnog kritikovanja učesnika u diskusiji, pa je sednica naglo privedena kraju. ${ }^{10}$

Izvršni komitet CK SKS uputio je Zaključke sa ove sednice Organizaciono-političkom sekretarijatu CK SKJ, ukazavši da je Savez komunista u razmatranju problema APKM polazio sa stanovišta razvoja jugoslovenske privrede u celini i da je zbog toga razvoj Kosova i Metohije bio usporen i znatno zaostao, što je ocenjeno štetnim za ukupnu jugoslovensku zajedni$\mathrm{cu}$. Neotklanjanje takvog stanja samo bi pospešilo razvoj iredentizma $\mathrm{u}$ Pokrajini usled širenja ekonomskog nezadovoljstva među stanovništvom albanske nacionalnosti.

Na sednici održanoj 6. i 7. jula 1964. Izvršni komitet CK SKJ je ocenio da su rezultati razvoja nerazvijenih krajeva Jugoslavije načelno povoljni, ali da je bilo izvesnih slabosti. Zatraženo je da se dalji razvoj ovih područja uklopi u opštu razvojnu politiku države, a metodi i instrumenti razvoja usklade sa jedinstvenim privrednim sistemom uz specifična rešenja kojima bi bili stvoreni uslovi za njihov brži razvoj. No, ostala su otvorena tri pitanja. Prvo, da li se može u određenim rokovima planski osigurati da razvoj nerazvijenih područja bude brži od prosečnog razvoja Jugoslavije ili to treba da bude stalan zadatak praktične ekonomske politike koji bi se ostvarivao u skladu sa materijalnim mogućnostima države. Drugo, da li Fond za razvoj nerazvijenih područja treba da posluje kao samostalna ustanova koja će usmeravati sredstva na pojedine republike u okviru opštih smernica politike razvoja ili da se usmeravanje sredstava na pojedina područja vrši na osnovu odluka Skupštine, kao i ko treba da vrši deobu sredstava Fonda na pojedine republike - Skupština ili Upravni odbor fonda. Treće, da li sredstva Fonda koristiti samo za privredna ulaganja ili i za podsticanje neprivrednih delatnosti, i kako rešavati problem prezaduženosti na ovim područjima - da li po opštim merilima za celu zemlju ili posebno. Diskusiju je presekao E. Kardelj koji je zatražio da se što pre kreiraju dugoročni planovi koji bi bili u skladu sa mogućnostima jugoslovenske privrede, odnosno da

$$
{ }^{10} \text { Isto. }
$$


se odrede sredstva u Fondu i da se „onda vidi koji je to maksimum koji može da učini naša privreda". ${ }^{11}$

U Nacrtu Rezolucije o smernicama za izradu Društvenog plana Jugoslavije za period od 1964. do 1970. godine istaknuto je da se problem razvoja nedovoljno razvijenih područja mora brže rešavati, jer predstavlja doprinos uspešnom razvoju jugoslovenske privrede i daljem napretku ekonomske osnovice ravnopravnosti jugoslovenskih naroda. Predložen je niz mera poput proširenja proizvodnje, povećanja produktivnosti rada i životnog standarda radnika, podsticanja ekonomskih interesa novoizgrađenih preduzeća u nerazvijenim područjima i uspostavljanja proizvodne saradnje sa preduzećima iz razvijenijih krajeva - tzv. integracionih procesa u privredi. Kako je naglašeno: „Sredstva Federacije treba da koriste za pomaganje ubrzanog razvoja nedovoljno razvijenih republika i APKM. Povećana ekonomska snaga razvijenih republika omogućiće im da pomognu brži razvoj pojedinih nedovoljno razvijenih regiona na svojim područjima. Društvenim planovima Jugoslavije potrebno je obezbediti i neophodna dopunska sredstva Federacije za pružanje pomoći nedovoljno razvijenim područjima za ostvarivanje bržeg razvoja i onih neprivrednih delatnosti, pre svega školstva, što je od značaja za postizanje bržeg porasta privrede i životnog standarda na ovim područjima". ${ }^{12}$

S druge strane, Sekretarijat PK SKS za KM je 27. avgusta 1964. razmatrao posledice hapšenja 80 lica uglavnom albanske nacionalnosti na Kosovu i Metohiji zbog neprijateljske delatnosti. Među uhapšenima je bilo intelektualaca, prosvetnih radnika, službenika, studenata, učenika i političkih rukovodilaca, što je podstaklo zaoštravanje međunacionalne situacije $u$ Pokrajini, dovelo do negativnih reakcija funkcionera Albanije i kritika od strane zapadnih medija koji su preneli vest da se „sprovodi teror nad albanskim življem u Jugoslaviji“. Ubrzo zatim, 29. septembra, Komisija za ideološki rad CK SKJ zaključila je da je i pored sprovođenja politike nacionalne ravnopravnosti i likvidacije hegemonizma u Jugoslaviji došlo do „preterane zaokupljenosti kadrova pitanjima ekonomskog položaja svojih republika, usled čega su pojedini postupci i izjave počeli da se negativno reflektuju i podležu nacionalističkim deformacijama“. Koliko je društveno-politička situacija u Jugoslaviji bila rovita pokazuje i sednica Izvršnog komiteta CK SKJ, održana 28. oktobra, na kojoj je J. Broz Tito istakao da se „mora menjati duh koji vlada u CK" i da u "jugoslovenskom rukovodstvu postoji kriza koja se mora rešiti do Kongresa“. Uputivši kritiku što u rukovodstvu SKJ nema jedinstva, on je rekao: „Šovinizam se razvija po republikama, a

${ }^{11}$ AJ, 507, SKJ, V, K-XX/1-44, Pregled sednica izvršnih komiteta CK SK republika, 3. jul 1964; AJ, 507, SKJ, III/102, Zapisnik sa sednice IK CK SKJ, 6-7. jul 1964.

${ }^{12}$ Isto. 
svi ukazuju na Beograd. Umešala se sitnoburžoaska stihija. Apsurdno je, ali moramo danas ponovo da postavljamo pitanje naših nacionalnih odnosa. Danas su mnogi naši i to rukovodeći komunisti nosioci nacionalističkih tendencija". ${ }^{13}$

Debata o Prednacrtu zakona o Fondu federacije za kreditiranje nedovoljno razvijenih republika i krajeva vođena je 4. novembra 1964. u Saveznoj skupštini sa ciljem da se omogući privredni rast i povećanje društvenog standarda $u$ manje razvijenim regionima, odnosno da se oni u što kraćem roku osnaže kako bi bili u stanju da sami dalje finansiraju sopstveni razvoj. Fond je trebalo da kreditira razvoj SR Bosne i Hercegovine, SR Crne Gore i SR Makedonije, kao i AP Kosova i Metohije do 1970. godine, pri čemu je zatraženo da se jasno definiše šta tačno država želi da postigne i razvija u nerazvijenim područjima. Savezna skupština je na zasedanju 24. i 25. novembra usvojila Rezoluciju o smernicama za izradu Društvenog plana Jugoslavije za period od 1964. do 1970. godine, dok je na sednici Izvršnog komiteta CK SKJ, održanoj 4. decembra, Ivan Gošnjak zatražio da se prilikom sastava budućeg CK SKJ vodi računa o nacionalnim manjinama. Na kraju sednice je podržano da u CK SKJ uđu četiri Albanca, dva Turčina i jedan Mađar. ${ }^{14}$

U takvim okolnostima održan je Osmi kongres SKJ od 7. do 13. decembra 1964. u Beogradu, na kojem je J. Broz Tito izrazio mišljenje da „Kongres mora posvetiti punu pažnju međunacionalnim odnosima, ali ne zbog toga što nacionalno pitanje kod nas predstavlja problem koju u principu nije rešen“. On je apelovao da se prevaziđu međunacionalne protivrečnosti koje su bile plod brzog i svestranog razvoja zemlje, posebno u sferi ekonomije. Zatražio je da se pojave šovinizma prate, otkrivaju i proučavaju, objasnivši da one proizilaze iz „etatističko-birokratskih tendencija koje sputavaju međunacionalne integracije“ i „unitarističkog ignorisanja društvenoekonomskih funkcija republika i autonomnih pokrajina“ uz zatvaranje „u svoje granice“, i kritikovao sve koji se proglašavaju za „zaštitnike nacionalnih interesa ovog ili onog naroda“. Založivši se za razvijanje zajedničke jugoslovenske kulture uz „svestrani i slobodni procvat nacionalnih kultura svih naroda i narodnosti udruženih jedinstvenim interesima i jedinstvenim socijalističkim društvenim sistemom“, Tito je naglasio potrebu ekonomskog osamostaljivanja nerazvijenih republika i AP Kosovo i Metohija kako bi

${ }^{13} \mathrm{AJ}, 507, \mathrm{SKJ}, \mathrm{V}, \mathrm{K}-\mathrm{XX} / 1-44$, Informacija o pojavama neprijateljske delatnosti u Pokrajini Kosovo i Metohija, 22. septembar 1964; AJ, 507, SKJ, VIII, II/2-b-(185-190), k. 14, Izveštaj o delatnosti Komisije za ideološki rad CK SKJ u periodu od Sedmog do Osmog kongresa SKJ, 29. septembar 1964; AJ, 507, SKJ, III/104, Zapisnik sa sednice IK CK SKJ, 28. septembar 1964.

14 „Прогрес недовољно развијених подручја - интерес читаве заједнице“, Борба, 5. 11. 1964, 3; AJ, 507, SKJ, III/106, Zapisnik sa sednice IK CK SKJ, 4. decembar 1964. 
sopstvenim snagama ostvarivali dalji ekonomski razvitak u interesu cele zajednice. Politiku bržeg razvoja ekonomski nedovoljno razvijenih područja treba sprovoditi u skladu sa objektivnim mogućnostima cele privrede, uz realizaciju ulaganja u do tada izgrađene kapacitete, širu tehničku i kadrovsku pomoć, forsiranje elastičnije kreditne politike i usmeravajuću ulogu SK, ocenio je jugoslovenski predsednik. U osvrtu na politiku prema nacionalnim manjinama, Broz je podsetio na Zaključke Izvršnog komiteta SKJ iz marta 1959. koji su za polaznu osnovu imali jedinstven tretman i jednak društveni položaj svih radnih ljudi, bez obzira na nacionalnu pripadnost, zatraživši potpuno ostvarivanje prava svih nacionalnosti, razvijanje i negovanje prijateljske, dobrosusedske i što svestranije saradnje sa zemljama maticama, kao i razvoj proizvodnih snaga autonomnih pokrajina i drugih krajeva gde žive etničke grupe. Budući da je najveća odgovornost u suzbijanju nacionalizma bila poverena SKJ, on je istakao: „Ako ne želimo da nam se jave ozbiljne teškoće na našem putu, mi moramo otvorenim očima da gledamo na još uvijek postojeće probleme nacionalnih odnosa“". ${ }^{15}$

U nastavku Osmog kongresa SKJ, E. Kardelj je primetio da „svakodnevni prakticizam i mnoštvo različitih trenutnih interesa čine ponekad da ljudi od drveća ne vide šumu“, odnosno da se ne sme zanemariti generalna politička linija SKJ. Pohvalivši napore partijske politike u podizanju stepena razvijenosti nedovoljno razvijenih područja, on je naglasio da nije zadovoljan rezultatima na Kosovu i Metohiji koje je u razvoju ostalo ispod jugoslovenskog proseka. Kardelj je zaključio da se „problemi materijalne i društveno-ekonomske prirode ne mogu rešiti prostim revolucionarnim dekretima ni silom ni pritiskom već prvenstveno demokratskom saradnjom naroda" i da SKJ ne nameće "nikakav model idealnog socijalističkog društva, ne uspostavlja nikakve dogme i ne stvara nikakve tehnokratske konstrukcije“. Aleksandar Ranković je kritikovao „pseudoliberalistička i malograđansko-anarhistična shvatanja" koja pokušavaju da destabilizuju SKJ, dok je Veljko Vlahović osudio mišljenje da je „nesreća što je Jugoslavija mnogonacionalna zajednica", ukazavši da je shvatanje po kojem će nacionalne razlike iščeznuti posle pobede revolucije naučno neodrživo. U svojstvu kongresnog delegata sa područja AP Kosovo i Metohija, Ali Šukrija je istakao da je između sedmog i osmog kongresa SKJ društveni bruto proizvod u Pokrajini porastao 45\%, nacionalni dohodak po glavi stanovnika $33 \%$, industrijska proizvodnja oko 2 puta, broj zaposlenih za oko 30.000 lica i odnos ukupne obradive površine sa $3 \%$ na $10 \%$. No, opšta produktiv-

15 Osmi kongres Saveza komunista Jugoslavije. Stenografske beleške, knj. I-III (Beograd: Kultura, 1965), 311; Љ. Димић, н. g., 378; К. Николић, H. g., 244; B. Petranović, n. d., 352; Добрица Ћосић, Пишчеви зайиси (1951-1968) (Београд: Филип Вишњић, 2001), 229; D. Bilandžić, $n$. d., 277. 
nost Kosova i Metohije ostala je ispod jugoslovenskog proseka, cene 80\% proizvoda bile su pod državnom kontrolom i na granici kupovne moći stanovništva, nedostajala je kontrola realizacije planova, visok natalitet je uzrokovao višak radne snage. Na kraju izlaganja, on je izrazio nadanje da će brži privredni razvoj AP Kosovo i Metohija pomoći jugoslovenska zajednica kroz intervenciju materijalnim i drugim sredstvima u skladu sa proklamovanom politikom SKJ. ${ }^{16}$

U Rezoluciji Osmog kongresa SKJ konstatovano je da je „u proteklom periodu stalno jačala i produbljivala se nacionalna ravnopravnost" $u$ Jugoslaviji, ali uz teškoće koje su proisticale iz „dubokih razlika u ekonomskoj snazi i mogućnostima razvitka raznih nacionalnih područja, administrativno-etatističkih elemenata u ekonomskim odnosima i subjektivnih slabosti u redovima SK“. Odbačena su stanovišta da su „nacije u našem socijalističkom društvenom razvoju preživele i da treba stvarati jedinstvenu jugoslovensku naciju“, kao izraz „birokratskog centralizma i unitarizma praktično ispoljavanog kroz ignorisanje političkih, društvenih, ekonomskih i drugih funkcija republika i autonomnih pokrajina". Posebno je zatraženo da se negativne pojave ne dozvole u obrazovanju, nauci, kulturi i umetnosti, da se neprestano radi na jačanju ravnopravnost naroda i narodnosti Jugoslavije i da se dalje ekonomski razvijaju nerazvijene republike i АП Kosovo i Metohija $u$ interesu cele jugoslovenske zajednice. Sa Kosova i Metohije $u$ CK SKJ izabrani su D. Mugoša, F. Hodža, A. Šukrija, V. Deva i Tankosava Simić, a u Kontrolnu komisiju Ilijaz Kurteši. Tako je na Osmom kongresu SKJ, prvi put posle Drugog svetskog rata, došlo do posrednog priznanja da "Narodna revolucija“ nije rešila nacionalno pitanje u Jugoslaviji uvođenjem federativnog oblika državnog uređenja, uklanjanjem „velikosrpske hegemonije“, forsiranjem „bratstva i jedinstva“ i ravnopravnosti naroda i narodnosti. Definitivnim odbacivanjem ideje nametanja jugoslovenstva od strane jugoslovenske federacije i podrškom skladnom razvoju svakog naroda i narodnosti, indirektno je podržana samostalnost nastupanja i delovanja jugoslovenskih republika i pokrajina. ${ }^{17}$

Opšti sabor Skupštine SR Srbije, prvi takve vrste, usvojio je 10. februara 1965. Rezoluciju o smernicama za izradu društvenog plana SRS do 1970. godine, dok je 15. februara Saveznoj skupštini dostavljen amandman grupe poslanika, na čelu sa Kadri Reufijem, na Predlog zakona o Fondu federacije za kreditiranje privrednog razvoja nedovoljno razvijenih republi-

\footnotetext{
${ }^{16}$ Isto.
}

17 J. Broz Tito je na plenumu CK SKJ održanom 13. decembra 1964. jednoglasno izabran za generalnog sekretara SKJ. Videti: Osmi kongres Saveza komunista Jugoslavije. Stenografske beleške, 311; Љ. Димић, н. g., 378; К. Николић, н. g., 244; B. Petranović, n. d., 352; Д. Ћосић, н. g., 229; D. Bilandžić, n. d., 277; AJ, 507, SKJ, II/26, Zapisnik sa Prve sednice CK SKJ, 12. decembar 1964. 
ka i krajeva. U amandmanu se tražilo da se Kosovu i Metohiji ustupe anuiteti po kreditima iz sredstava Federacije u iznosu 2.800 miliona dinara godišnje, zbog toga što predviđeno učešće Federacije od 4.600 miliona dinara u izgradnji energetskih objekata nije bilo dovoljno. Dalekosežni zaključci Osmog kongresa SKJ došli su do izražaja na sednici Izvršnog komiteta CK SKJ 26. februara kada je Jovan Veselinov, povodom rada organizacije SK u Jugoslovenskoj narodnoj armiji (JNA), postavio pitanje „zašto se više ne otvore vrata za školovanje kadrova iz nacionalnih manjina" i konstatovao da „na terenu postoji osećaj diskriminacije prema Šiptarima i Mađarima“, na šta mu je Ivan Gošnjak odgovorio da diskriminacije u vojsci nema, dok je J. Broz Tito istakao da „u svemu ne bi trebalo gledati samo nacionalni kriterijum već i neke druge“. Na snagu je 4. marta stupio Zakon kojim je osnovan Fond federacije za kreditiranje privrednog razvoja privredno nedovoljno razvijenih republika i krajeva, ali je već 26 . marta plenum Centralnog veća Saveza sindikata Jugoslavije podržao privremene mere SIV-a o zamrzavanju cena i svođenju investicione potrošnje u planirane okvire, kako bi došlo do stabilizacije tržišta i privrednih kretanja u državi. ${ }^{18}$

Peti kongres SK Srbije održan je od 11. do 14. maja 1965. u Beogradu i na njemu je izabran novi CK SKS, a za sekretara ovog tela ponovo imenovan J. Veselinov. Kongres je konstatovao da se pitanje međunacionalnih odnosa „ne može rešiti jednom zauvek i skinuti sa dnevnog reda“, naglasio punu ravnopravnost svih naroda i narodnosti uz poštovanje njihovih osobenosti i daljeg svestranog nacionalnog razvitka, obavezao društvenu zajednicu na stvaranje uslova za razvoj privredno nerazvijenih krajeva kao ekonomskog interesa cele države i svakog naroda, ukazao da „samo slobodne i ravnopravne nacije mogu naći pravi interes za zajednički život" i istakao da se kod narodnosti „sve više razvija socijalistička svest i uverenje da je njihova sudbina najtešnje povezana sa sudbinom naroda Jugoslavije“. Pohvaljeni su napori Saveza komunista na iskorenjivanju ekonomske i društvene zaostalost u Kosovu i Metohiji i pozvani društveno-politički radnici da nauče jezik narodnosti u sredini u kojoj rade. Sa područja Kosova i Metohije u Izvršni komitet CK SKS izabrani su Dž. Nimani i T. Simić. ${ }^{19}$

Izvršni komitet CK SKJ je 28. maja 1965. zaključio da bez ekonomskih reformi nije moguće doneti Društveni plan Jugoslavije do 1970. godi-

${ }^{18}$ AJ, 507, SKJ, III/108, Zapisnik sa sednice IK CK SKJ, 28. januar 1965; AJ, 130, SIV, K-685, Amandman na član 40, 15. februar 1965; AJ, 507, SKJ, III/109, Zapisnik sa sednice IK CK SKJ, 26. februar 1965; Hronologija radničkog pokreta i SKJ 1919-1979, urednik Dušan Živković, knj. III (Beograd: Narodna knjiga, 1980), 243; AJ, 507 SKJ, III/110, Zapisnik sa sednice IK CK SKJ, 5. maj 1965.

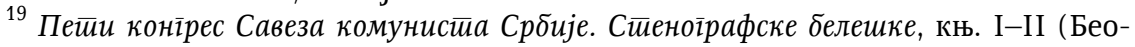
град: Култура, 1966), 23; Љ. Димић, н. g., 381. 
ne, sa čime se Broz načelno složio založivši se da se ne ukidaju nerentabilna preduzeća kako se ne bi povećala nezaposlenost. Produbljivanje ekonomske krize podstaklo je SIV i Saveznu skupštinu da 25. jula usvoje oko 30 zakonskih propisa kojima je otpočela velika privredna reforma u Jugoslaviji. Tako su planirane opšta revizija cena, deflaciona politika i ekonomsko otvaranje države prema svetu, što je pratilo donošenje Zakona o paritetu dinara kojim je izvršena zamena starih dinara za nove u odnosu 100: 1 i utvrđen novi kurs od 12,5 novih dinara za 1 američki dolar. Kako je u pitanju bio veoma ambiciozan državni projekat, Josip Broz Tito je 8. avgusta ukazao na posledice oličene u padu životnog standarda stanovništva. Krajem juna Savezna skupština je imenovala Upravni odbor Fonda federacije za kreditiranje privrednog razvoja privredno nedovoljno razvijenih republika i krajeva na čelu sa Marjanom Breceljem kao predsednikom, dok je jedan od članova ovog tela bio V. Deva. ${ }^{20}$

Na sednici Izvršnog komiteta CK SKJ, održanoj 12. i 13. novembra 1965, Broz je izrazio nezadovoljstvo tempom sprovođenja privredne reforme, zatražio da se nove investicije svedu na najrealnije osnove i istakao da je za nerazvijene republike i krajeve predviđen Fond od 800 milijardi dinara. Primetivši da je po pitanju nacionalnih odnosa situacija u Jugoslaviji gora nego pre Osmog kongresa SKJ, izneo je ideju da se $75 \%$ kapitala iz fondova Federacije prepusti republikama, kako bi se prestalo sa državnom centralizacijom i kritikama republika na račun Federacije. U diskusiji, Petar Stambolić je uočio da iz ekonomskih problema proističu međunacionalni sukobi, V. Vlahović ukazao da se u nerazvijenim krajevima povećava strah za budućnost raspodele sredstava jugoslovenske federacije i da se slabo rešavaju problemi u vezi sa koncepcijom i ulogom Fonda federacije za razvoj nerazvijenih republika i krajeva, a J. Veselinov pohvalio jedan od retkih rentabilnih slučajeva proces kooperacije između Fabrike "Crvena zastava" u Kragujevcu i Fabrike amortizera u Prištini. Miloš Minić je preneo da se u Beogradu priča vic: „Šta će biti ako propadne ova reforma? Doći će druga“, dok je A. Ranković govorio o krizi međusobnog poverenja i slabom kriterijumu za prijem u SK. Edvard Kardelj je kritikovao ostatke unitarističko-centralističkih tendencija i „velikosrpskog nacionalizma“ u SR Srbiji, naglasivši: „Nismo se mi u Jugoslaviji ujedinili zbog Jugoslavije, nego smo se ujedinili zbog socijalizma“. Uz napomenu da manje razvijene republike strahuju da će deetatizacija i decentralizacija dovesti do smanjenja podrške jugoslovenske federacije njihovom razvitku, on je ukazao: „Upravo

${ }^{20}$ AJ, 507, SKJ, III/111, Zapisnik sa sednice IK CK SKJ, 28. maj 1965; Hronologija radničkog pokreta..., 247; Josip Broz Tito, Govori i članci, knj. XX (Zagreb: Naprijed, 1970), 354; AJ, 130, SIV, K-685, Fond federacije za kreditiranje privrednog razvoja privredno nedovoljno razvijenih krajeva, 8. novembar 1965. 
zbog toga što je Srbija najveća naša republika i srpska nacija najveća naša nacija u Jugoslaviji, od njenog stava i njene orijentacije daleko više zavisi nego od stava bilo koje druge nacije". ${ }^{21}$

Otvaranje nacionalnog pitanja u Jugoslaviji, u kojem je bila sadržana problematika nacionalnih manjina, podstakla je narastajuća ekonomska kriza izazvana slabom održivošću državnog sistema socijalističkog samoupravljanja u privredi. U cilju suzbijanja iredentizma među Albancima, koji su činili dve trećine stanovništva Kosova i Metohije, SFRJ nije odustajala od daljih privrednih ulaganja u APKM. U takvim okolnostima, rukovodstvo Pokrajinskog komiteta SKS za KM je nastojalo da u prvoj polovini 1964. godine izdejstvuje veće državne investicije za Kosovo i Metohiju, uputivši zamerke kadrovima iz CK SKS da nisu dovoljno učinili na planu sprovođenja politike bržeg razvoja Pokrajine. Shodno tome, Izvršni komitet CK SKJ je doneo odluku da se dalji razvoj Kosova i Metohije uklopi u razvojnu politiku jugoslovenske države i to preko odgovarajućeg Fonda koji bi bio formiran u tu svrhu, što je potvrđeno u nacrtu Društvenog plana Jugoslavije za period do 1970. godine. Na Osmom kongresu SKJ, održanom u decembru 1964, Josip Broz Tito je podržao dalji razvoj nerazvijenih jugoslovenskih republika i AP Kosovo i Metohija kao interes cele jugoslovenske federacije i potvrđena je politika afirmacije ravnopravnosti nacionalnih manjina. Odbačena je ideja stvaranja jugoslovenske nacije i iskazana potreba razvoja pojedinačnih nacionalnih kultura objedinjenih u socijalističku Jugoslaviju. Sa Kosova i Metohije u CK SKJ izabrani su D. Mugoša, F. Hodža, A. Šukrija, V. Deva i T. Simić. Zakon kojim je osnovan Fond federacije za kreditiranje privredno nedovoljno razvijenih republika i krajeva stupio je na snagu $u$ martu 1965. U pitanju je bila velika pobeda rukovodstva Kosova i Metohije, koje je uspelo da na krilima otvaranja nacionalnog pitanja u Jugoslaviji izdejstvuje da se APKM u svojim ekonomskim potraživanjima praktično izjednači sa nerazvijenim jugoslovenskim republikama Bosnom i Hercegovinom, Makedonijom i Crnom Gorom, kao i da kadrovski bude više prisutno u saveznim organima. Do kraja 1965. godine, do izražaja su došli pojačano nezadovoljstvo i strepnja najvišeg jugoslovenskog rukovodstva da li će ekonomska kriza dovesti do daljeg pada standarda stanovništva i dodatno zaoštriti međunacionalne antagonizme širom Jugoslavije, a posebno na Kosovu i Metohiji.

${ }^{21}$ AJ, 507, SKJ, III/113, Zapisnik sa sednice IK CK SKJ, 12-13. novembar 1965; AJ, 507, SKJ, III/114, Zapisnik sa sednice IK CK SKJ, 16. decembar 1965; Љ. Димић, н. g., 381; B. Petranović, n. d., 353; D. Bilandžić, n. d., 305. 


\section{IZVORI I LITERATURA}

- Arhiv Jugoslavije (AJ), fond 507 Savez komunista Jugoslavije; 130 Savezno izvršno veće.

- Arhiv Srbije (AS), fond Đ-2 Savez komunista Srbije.

- Josip Broz Tito. Govori i članci, knj. XX. Zagreb: Naprijed, 1970.

- Osmi kongres Saveza komunista Jugoslavije. Stenografske beleške, knj. I-III. Beograd: Kultura, 1965.

- Пейи конірес Савеза комунисйа Србије. Сйеноірафске белешке, књ. I-II. Београд: Култура, 1966.

- Početak kraja SFRJ. Stenogram i drugi prateći dokumenti proširene sednice Izvršnog komiteta CK SKJ održane 14-16. marta 1962. godine. Priredio Miodrag Zečević. Beograd: Printer Komerc, 1998.

- Борба, новембар 1964.

- Bilandžić, Dušan. Historija Socijalističke Federativne Republike Jugoslavije: glavni procesi 1918-1985. Zagreb: Školska knjiga, 1985.

- Bjelajac, Mile. „Karakter jugoslovenskog centralizma u svetlu analize tajne sednice Izvršnog komiteta Centralnog komiteta Saveza komunista Jugoslavije marta 1962. godine“. U: Dijalog povjesničara-istoričara 7, Zbornik radova. Urednici Hans-Georg Fleck i Igor Graovac, 373-390. Zagreb: Friedrich Naumann Stiftung, 2003.

- Ћосић, Добрица. Пишчеви зайиси (1951-1968). Београд: Филип Вишњић, 2001.

- Gatalović, Miomir. „Prerastanje Autonomne Kosovsko-metohijske oblasti u Autonomnu pokrajinu Kosovo i Metohiju 1959-1963.", Istorija 20. veka XXXIII, br. 1 (2015), 77-94.

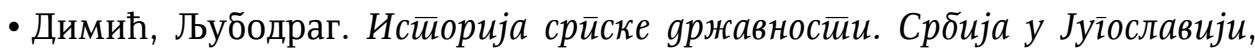
књ. III. Нови Сад: Будућност, 2001.

- Hronologija radničkog pokreta i SKJ 1919-1979. Urednik Dušan Živković, knj. III. Beograd: Narodna knjiga, 1980.

- Николић, Коста. Србија у Тит̄овој Јуі̄ославији (1945-1980). Београд: Завод за уџбенике, 2011.

- Petranović, Branko. Istorija Jugoslavije 1918-1988. Socijalistička Jugoslavija, knj. III. Beograd: Nolit, 1988. 
Miomir Gatalović

\section{THE EFFECT OF THE OPENING OF THE NATIONAL QUESTION IN YUGOSLAVIA ON THE CREATION OF THE STATE POLICY TOWARDS KOSOVO AND METOHIJA 1964-1965}

\section{Summary}

The opening of the national question in Yugoslavia was incited by a growing economic crisis caused by poor sustainability of the state system of socialist self-management. In order to combat irredentism which was spreading among the Albanians, who made up two thirds of the population of Kosovo and Metohija, Yugoslavia would not desist from further economic investments in the Autonomous Province of Kosovo and Metohija (APKM). In such circumstances, the leadership of the Provincial Committee of the League of Communists of Serbia for Kosovo and Metohija tried to obtain greater government investment for the APKM in the first half of 1964, addressing objections to the leadership of the Serbian League of Communists that they were negelcting the implementation the policy of faster development of Kosovo and Metohija. Accordingly, the Executive Committee of the Central Committee of the League of Communists of Yugoslavia (LCY) decided to frame the further development of the APKM into the development policy of the Yugoslav state and use the corresponding Fund that was established for this purpose. At the Eighth Congress of the LCY, held in December 1964, Josip Broz Tito supported the further development of undeveloped Yugoslav republics and the APKM as the interest of the whole Yugoslav federation and the policy of affirmation of the equality of national minorities was confirmed. With regard to the national question, the idea of creation of the Yugoslav nation was rejected and the need to develop individual national cultures united in socialist Yugoslavia was expressed. The law which established the Federal Fund for Lending for the Economic Development of Insufficiently Developed Republics and Regions came into force in March 1965. It was a major victory for the leadership of Kosovo and Metohija, which managed to use the opening of the national question in Yugoslavia to equalize the APKM in their economic claims with undeveloped Yugoslav republics of Bosnia and Herzegovina, Macedonia and Montenegro, as well as make the leadership from the APKM more present in the federal authorities. 
KEYWORDS: Kosovo and Metohija, the national question, Yugoslavia, the economic crisis, Josip Broz Tito, the state policy, the League of Communists of Yugoslavia, the national minorities

\section{L'EFFET DE L'OUVERTURE DE LA QUESTION NATIONALE EN YOUGOSLAVIE SUR LA CREATION DE LA POLITIQUE DE L'ÉTAT VERS KOSOVO ET MÉTOCHIE 1964-1965}

\section{Sommaire}

L'ouverture de la question nationale en Yougoslavie a été incité par une crise économique croissante causée par une mauvaise durabilité du système étatique de l'autogestion socialiste dans l'économie. Afin de lutter contre l'irrédentisme qui se répandait parmi les Albanais, qui représentaient les deux tiers de la population du Kosovo et Métochie, la Yougoslavie n'a pas cessé les investissements économiques dans la province autonome du Kosovo et Métochie (PAKM). Dans de telles circonstances, la direction du Comité provincial de la Ligue des communistes de Serbie pour le Kosovo et Métochie a tenté d'obtenir un plus grand investissement du gouvernement pour la PAKM dans la première moitié de 1964, adressant des objections au personnel de la Ligue des communistes de Serbie qu'ils n'ont pas fait assez en termes de mise en œuvre de la politique de développement plus rapide du Kosovo et Métochie. En conséquence, le Comité exécutif du Comité central de la Ligue des communistes de Yougoslavie (LCY) a décidé d'intégrer la poursuite du développement du PAKM dans la politique de développement de l'Etat yougoslave et par le Fonds correspondant qui a été créé à cet effet. Au huitième Congrès de la LCY, tenue en Décembre 1964, Josip Broz Tito a soutenu le développement des républiques yougoslaves sous-développés et de l'PAKM a été defini comme l'intérêt de toute de la fédération yougoslave et la politique d'affirmation de l'égalité des minorités nationales a été confirmée. En ce qui concerne la question nationale, l'idée de la création de la nation yougoslave a été rejetée et la nécessité de développer les cultures nationales individuelles réunies en Yougoslavie socialiste a été exprimé. La loi qui a créé le Fonds de Fédération des prêts pour le développement économique des républiques et les regions pas suffisamment développées est entrée en vigueur en Mars 1965. C'etait une grande victoire pour les dirigeants du Kosovo et Métochie, qui ont réussi à utiliser l'ouverture de la question nationale en Yougoslavie pour égaliser la PAKM dans leurs revendications économiques avec les républiques non développées yougoslaves de Bosnie-Herzégovine, la Macédoine et le 
Monténégro, ainsi que de rendre le personnel de la PAKM plus présent dans les autorités fédérales.

MOTS-CLÉS: Kosovo et Métochie, la question nationale, la Yougoslavie, la crise économique, Josip Broz Tito, la politique de l'Etat, la Ligue des communistes de Yougoslavie, les minorités nationales 